\author{
Руденко С. А. ${ }^{1}$, канд. мед. наук, завідувач відділу хірургічного лікування ішемічної хвороби серця \\ Федьків С. В. ${ }^{1,2}$, д-р мед. наук, завідувач відділу променевої діагностики, професор кафедри радіології \\ Поташев С. В. ${ }^{1}$, канд. мед. наук, старший науковий співробітник відділу променевої діагностики \\ Йоффе Н. 0. ${ }^{1}$, канд. мед. наук, завідувач відділення анестезіології \\ Лазоришинець В. В. ${ }^{1}$, академік НАМНУ, директор, професор \\ ${ }^{1}$ ДУ «Національний інститут серцево-судинної хірургії імені М. М. Амосова НАМН України», м. Київ, Україна \\ ${ }^{2}$ Національна медична академія післядипломної освіти імені П. Л. Шупика, м. Київ, Україна
}

\title{
Результати протезування мітрального клапана у хворих з ішемічною мітральною недостатністю
}

\begin{abstract}
Резюме. Функціональна ішемічна мітральна недостатність розвивається у 10-20\% пацієнтів з ішемічною хворобою серця (IXC) і справляє значний негативний вплив на прогноз виживаності хворих. Хронічна функціональна ішемічна мітральна недостатність виявляється в 11-19\% пацієнтів, яким виконують коронарографію при IXC, і у 20-30 \% пацієнтів, яким виконують аортокоронарне шунтування.

У період 2016-2017 рр. було виконано 49 протезувань мітрального клапана в поєднанні з вінцевим шунтуванням у хворих з мітральною недостатністю ішемічного генезу на базі Національного інституту серцевосудинної хірургії НАМН України. Серед цієї категорії пацієнтів чоловіків було 33 (67,3 \%), а жінок - 16 $(32,6 \%)$. Середній вік становив $62,8 \pm 7,4$ року. У переважної більшості хворих $(73,5 \%)$ в анамнезі відзначалась гіпертонічна хвороба. Ендокринологічно підтверджений діагноз цукрового діабету був у 9 (18,4 \%) пацієнтів. Показники фракції викиду варіювали в межах від 20 до $56 \%$ із середнім значенням 41,2 $\pm 8,7 \%$. У $61,2 \%(n=30)$ випадків у хворих діагностовано трьохсудинне ураження вінцевих артерій, у 20,4\% (10) були уражені дві вінцеві артерії і у 18,4 \% (9) - одна вінцева артерія. Гостра серцева недостатність II ступеня і вище, що потребувала інотропної підтримки більше ніж 24 години в післяопераційному періоді, виникла у 24,5 \% (12) випадках. Гостре порушення мозкового кровообігу спостерігалось в одного пацієнта (3,6 \%). Доопераційна тяжкість стану хворих цієї групи та післяопераційні ускладнення призвели до того, що середній термін перебування у відділенні інтенсивної терапії становив 128,3 \pm 74,5 години, а тривалість госпіталізації - 11,7 \pm 4,4 дня. Післяопераційна летальність після хірургічної корекції такої патології в нашому дослідженні сягала 4,1 \%. Протезування мітрального клапана є ефективним хірургічним методом лікування ішемічної мітральної недостатності з добрими безпосередніми результатами за неможливості відновити компетентність клапана пластичними методиками. Частота післяопераційних ускладнень та рівень летальності обумовлений тяжким доопераційним станом хворих.
\end{abstract}

Ключові слова: ішемічна мітральна недостатність, протезування мітрального клапана, ішемічна хвороба серия.

Первинна мітральна недостатність являє собою результат дисфункції стулок мітрального клапана. Вторинна, або функціональна, мітральна недостатність виникає при ішемічному пошкодженні лівого шлуночка без прямого пошкодження структур мітрального клапана і підклапанного апарату, що призводить до виникнення регургітації на мітральному клапані при інтактних стулках. При цьому відбувається «геометрична деформація» мітрального клапанного апарату і виникає його некомпетентність. Функціональна ішемічна мітральна недостатність розвивається у 10-20\% пацієнтів з ішемічною хворобою серця (IXC) і справляє значний негативний вплив на прогноз виживаності хворих. Хронічна функціональна ішемічна мітральна недостатність виявляється в 11-19\% пацієнтів, яким виконують коронарографію при IXC, і у 20-30 \% пацієнтів, яким виконують аортокоронарне шунтування $[2,3,6]$.

Патофізіологія ішемічної мітральної недостатності неоднорідна. Загальні механізми включають несприятливе ремоделювання лівого шлуночка (як глобальне, так і місцеве), яке викликає дилатацію мітрального кільця і збільшення відстані між папілярними м'язами, втрату сили змикання через незадовільну скоротливість лівого шлуночка та його дисинхронію.

У разі виникнення симптомів ішемічної мітральної недостатності основним видом лікування є хірургіч- 
ний. У багатьох випадках методом вибору залишається протезування мітрального клапана.

Мета роботи: проаналізувати результати протезування мітрального клапана у хворих з ішемічною мітральною недостатністю.

Матеріали та методи дослідження. У період 20162017 рр. було виконано 49 протезувань мітрального клапана в поєднанні з вінцевим шунтуванням у хворих 3 мітральною недостатністю ішемічного генезу на базі Національного інституту серцево-судинної хірургії НАМН України. До цієї групи увійшли пацієнти з регургітацією II ступеня і вище за Carpentier.

Серед цієї категорії пацієнтів чоловіків було 33 (67,3\%), а жінок - 16 (32,6\%). Середній вік становив $62,8 \pm 7,4$ року. У переважної більшості хворих (73,5 \%) в анамнезі відзначалась гіпертонічна хвороба. Ендокринологічно підтверджений діагноз цукрового діабету був у $9(18,4 \%)$ пацієнтів.

Функціональний стан пацієнтів відображений у таблиці 1. У I функціональному класі за NYHA був лише один хворий. У II функціональному класі за NYHA $29(59,2 \%)$ пацієнтів. Решта $19(38,8 \%)$ прооперованих перебували в III-IV функціональному класі за NYHA. Причому 8 (22,5 \%) хворих були в IV функціональному класі за NYHA, тобто кожен п'ятий пацієнт був вкрай тяжким.

Одним з основних методів визначення ступеня мітральної недостатності була ехокардіографія (ЕхоКГ). При аналізі даних ЕхоКГ слід звернути увагу на показники кінцево-діастолічного об'єму (КДО) та кінцевосистолічного об'єму (КСО) лівого шлуночка (таблиця 2). Так, середнє значення КДО досягало 237,7 $\pm 62,6$ мл, а КСО лівого шлуночка - 136,8 \pm 42,5 мл. Показники фракції викиду (ФВ) варіювали в межах від 20 до $56 \%$ із середнім значенням $41,2 \pm 8,7 \%$.

Зазначена патологія включає не тільки наявність зворотного току на мітральному клапані, а ще й IXC, що супроводжується стенозами вінцевих артерій. Для верифікації ураження вінцевого русла серця всім хворим було виконано коронаровентрикулографію (КВГ) (таблиця 3). Згідно з даними КВГ середня кількість уражених вінцевих артерій на кожного пацієнта становила $2,5 \pm 0,9$.

У 61,2 \% (30) випадків у хворих діагностовано трьохсудинне ураження вінцевих артерій, у 20,4 \% (10) були уражені дві вінцеві артерії і у 18,4 \% (9) - одна вінцева артерія. Найчастіше ураження локалізувалося в передній міжшлуночковій гілці лівої вінцевої артерії $(83,7 \%)$. Рідше була скомпрометована огинаюча гілка лівої вінцевої артерії (73,5 \%). Стовбур правої вінцевої артерії був уражений вдвічі частіше, ніж лівої $(20,4 \%$ проти $10,2 \%)$. При ураженні стовбура правої вінцевої артерії оклюзія спостерігалася в $40 \%$, у той час як при ураженні стовбура лівої вінцевої артерії оклюзія мала місце тільки в $20 \%$. Але найбільше співвідношення

\section{Таблиця 1}

Розподіл пацієнтів за NYHA

\begin{tabular}{lc} 
Функціональний клас & $\begin{array}{c}\text { Кількість пацієнтів } \\
\mathbf{n = 4 9}\end{array}$ \\
\hline NYHA I & $1(2 \%)$ \\
\hline NYHA II & $29(59,2 \%)$ \\
\hline NYHA III & $11(22,5 \%)$ \\
\hline NYHA IV & $8(16,3 \%)$
\end{tabular}

\section{Таблиця 2}

Дані ехокардіографічного дослідження

\begin{tabular}{lc} 
Показник & Значення \\
\hline КДО (мл) & $237,7 \pm 62,6$ \\
\hline КСО (мл) & $136,8 \pm 42,5$ \\
\hline УО (мл) & $95,9 \pm 30,2$ \\
\hline ФВ (\%) & $41,2 \pm 8,7$
\end{tabular}

\section{Таблиця 3}

Розподіл уражень вінцевих артерій

\begin{tabular}{lcc} 
Назва артерії & $\begin{array}{c}\text { Кількість хворих } \\
\text { з ураженням }\end{array}$ & Кількість оклюзій \\
\hline Стовбур ЛВА & $5(10,2 \%)$ & $1(2 \%)$ \\
\hline ПМШГЛВА & $41(83,7 \%)$ & $15(30,6 \%)$ \\
\hline ОГЛВА & $36(73,5 \%)$ & $13(26,5 \%)$ \\
\hline Стовбур ПВА & $10(20,4 \%)$ & $4(8,2 \%)$ \\
\hline ПВА & $27(55,1 \%)$ & $13(26,5 \%)$
\end{tabular}

Примітка. ЛВА - ліва вінцева артерія; ПВА - права вінцева артерія; ПМШГ ЛВА - передня міжшлуночкова гілка лівої вінцевої артерії; ОГ ЛВА - огинаюча гілка лівої вінцевої артерії.

оклюзій до ураження було діагностовано в правій вінцевій артерії $(48,1 \%)$ (таблиця 3).

Результати та обговорення. Протокол хірургічного лікування цих хворих, розроблений у НICCX ім. М. М. Амосова, включає введення кардіоплегічного розчину при штучному кровообігу як антеградно, так і в кожний підшитий до серця графт, що дозволяє захистити повністю весь міокард серця. Середній час перетискання аорти при проведенні протезування мітрального клапана становив $115,7 \pm 30,1$ хвилини (таблиця 4). Тривалий час перетискання аорти можна пояснити не тільки великим об'ємом шунтування вінцевих артерій, у середньому $3,2 \pm 1,3$ шунта на пацієнта, а й тим, що в деяких випадках протезування виконувалось після невдалих спроб пластики клапана.

Тривале перетискання аорти відповідно призводило до збільшення часу штучного кровообігу. При протезуванні мітрального клапана він досягав 193,4 \pm 40,4 хв. Гостра серцева недостатність II ступеня і вище, 


\section{Таблиця 4}

Характеристики інтра- та післяопераційного періоду

\begin{tabular}{lc} 
Показник & Кількість хворих \\
\hline Час перетискання аорти & $115,7 \pm 30,1$ хв \\
\hline Час штучного кровообігу & $193,4 \pm 40,4$ хв \\
\hline Середня кількість шунтів на 1 хворого & $3,2 \pm 1,3$ \\
\hline Час штучної вентиляції легень (годин) & $27,5 \pm 64,8$ \\
\hline Гостре порушення мозкового кровообігу & $1(3,6 \%)$ \\
\hline $\begin{array}{l}\text { Гостра серцева недостатність II-ІІІ сту- } \\
\text { пеня }\end{array}$ & $12(24,5 \%)$ \\
\hline $\begin{array}{l}\text { Перебування у відділенні інтенсивної } \\
\text { терапії (год) }\end{array}$ & $128,3 \pm 74,5$ \\
\hline Тривалість госпіталізації (дні) & $11,7 \pm 4,4$ \\
\hline Летальність & $2(4,1 \%)$
\end{tabular}

що потребувала інотропної підтримки більше ніж 24 години в післяопераційному періоді, виникла у $24,5 \%$ (12) випадках. Гостре порушення мозкового кровообігу спостерігалось в одного пацієнта (3,6 \%) (таблиця 4). Доопераційна тяжкість хворих цієї групи та післяопераційні ускладнення призвели до того, що середній термін перебування у відділенні інтенсивної терапії становив $128,3 \pm 74,5$ години, а тривалість госпіталізації $11,7 \pm 4,4$ дня. Післяопераційна летальність після хірургічної корекції зазначеної патології в нашому дослідженні 4,1 \% [2]. Частота та структура післяопераційних ускладнень та летальності відповідає показникам більшості провідних закордонних центрів [1-6].

Висновки. Протезування мітрального клапана $є$ ефективним хірургічним методом лікування ішемічної мітральної недостатності з добрими безпосередніми результатами за неможливості відновити компетентність клапана пластичними методиками. Частота післяопераційних ускладнень та рівень летальності обумовлений тяжким доопераційним станом хворих.

\section{Список використаних джерел References}

1. Acker MA, Parides MK, Perrault LP, Moskowitz AJ, Gelijns AC, Voisine P, et al. Mitral-valve repair versus replacement for severe ischemic mitral regurgitation. $\mathrm{N}$ Engl J Med. 2014;370:23-32. https://doi.org/10.1056/ NEJMoa1312808

2. Chan KM, Punjabi PP, Flather M, Wage R, Symmonds K, Roussin I, et al. Coronary artery bypass surgery with or without mitral valve annuloplasty in moderate functional ischemic mitral regurgitation: final results of the Randomized Ischemic Mitral Evaluation (RIME) trial. Circulation. 2012;126:2502-10. https://doi.org/10.1161/ CIRCULATIONAHA.112.143818

3. Chatterjee S, Tripathi B, Virk HU, Ahmed M, Bavishi C, Krishnamoorthy P, et al. Does surgical repair of moderate ischemic mitral regurgitation improve Survival? A systematic review. Curr Cardiol Rep. 2016;18:22. https:// doi.org/10.1007/s11886-016-0701-5

4. Glower DD. Surgical approaches to mitral regurgitation. J Am Coll Cardiol. 2012;60:1315-22. https://doi. org/10.1016/j.jacc.2011.11.081

5. Kron IL, Hung J, Overbey JR, Bouchard D, Gelijns AC, MoskowitzAJ, etal. Predicting recurrent mitral regurgitation after mitral valve repair for severe ischemic mitral regurgitation. J Thorac Cardiovasc Surg. 2015;149:752-61. e1. https://doi.org/10.1016/j.jtcvs.2014.10.120

6. MacHaalany J, Sénéchal M, O’Connor K, Abdelaal E, Plourde G, Voisine P, et al. Early and late mortality after repair or replacement in mitral valve prolapse and functional ischemic mitral regurgitation: a systematic review and meta-analysis of observational studies. Int $\mathbf{J}$ Cardiol. 2014;173(3):499-505. https://doi.org/10.1016/j. ijcard.2014.02.029

\title{
Конфлікту інтересів немає.
}

\section{Outcomes of Mitral Valve Replacement in Patients with Ischemic Mitral Insufficiency}

\author{
Rudenko S. A. ${ }^{1}$, Fedkiv S. V. ${ }^{1,2}$, Potashev S. V. ${ }^{1}$, Ioffe N. O. ${ }^{1}$, Lazoryshynets V. V. ${ }^{1}$ \\ ${ }^{1}$ National Amosov Institute of Cardiovascular Surgery, Kyiv, Ukraine \\ ${ }^{2}$ Shupyk National Medical Academy of Postgraduate Education, Kyiv, Ukraine
}

Summary. Functional ischemic mitral insufficiency develops in 10-20\% of patients with coronary heart disease (CHD) and has significant negative impact on the potential for patient survival. Chronic functional ischemic mitral insufficiency is found in 11-19\% of patients undergoing coronary angiography with CHD and in 20-30\% of patients undergoing coronary artery bypass grafting.

In the period from 2016 to 2017,49 procedures of mitral valve replacement in conjunction with coronary artery bypass grafting were performed in patients with ischemic mitral insufficiency at the premises of the National Institute of Cardiovascular Surgery of the National Academy of Medical Sciences of Ukraine. There were $33(67.3 \%)$ men and 16 (32.6\%) women in this category of patients. The mean age was $62.8 \pm 7.4$ years. The overwhelming majority of patients 
(73.5\%) had the history of hypertension. Endocrinologically confirmed diagnosis of diabetes was found in 9 (18.4\%) patients. Ejection fraction varied from $20 \%$ to $56 \%$ with a mean value of $41.2 \pm 8.7 \%$. In $61.2 \%$ (30) of cases, the patients had three-vessel lesions of the coronary arteries; in 20.4\% (10), two coronary arteries were affected; and $18.4 \%$ (9) of patients had one coronary artery. Degree II or higher acute heart failure requiring inotropic support for more than 24 hours in the postoperative period occurred in $24.5 \%$ (12) cases. Acute cerebrovascular accident was observed in one patient (3.6\%). Preoperative severity of condition in patients of this group as well as postoperative complications determined the length of stay in the intensive care unit of $128.3 \pm 74.5$ hours, and the duration of hospitalization of $11.7 \pm 4.4$ days. Postoperative mortality after surgical repair of this pathology in our study was $4.1 \%$ (2). Mitral valve replacement is an effective surgical method for the treatment of ischemic mitral insufficiency with good direct results when it is impossible to restore the valve competence by means of plasty. The frequency of postoperative complications and mortality rate are due to severe preoperative state of patients.

Keywords: ischemic mitral insufficiency, mitral valve replacement, coronary heart disease.

Стаття надійшла в редакцію 24.07.2019 р. 